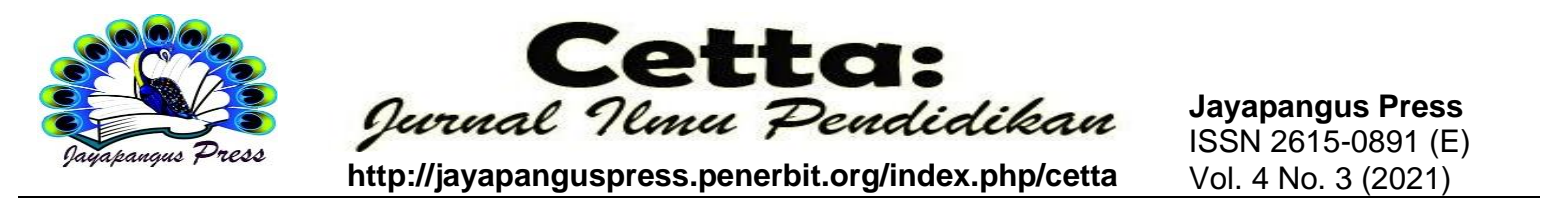

\title{
Pengaruh Implementasi Model Pembelajaran Group Investigation Dan Learning Cycle 5E Terhadap Prestasi Belajar Agama Hindu Dan Kreativitas Bermain Mind Mapping Siswa Kelas V Sekolah Dasar Negeri 17 Dauh Puri
}

\author{
I Made Dedy Paramartha \\ SDN Tulangampiang Denpasar \\ pramarthadedy@gmail.com
}

\begin{tabular}{l}
\hline Keywords: \\
\hline Model of \\
learning, Group \\
Investigation; 5 E \\
Learning Cycle; \\
Achievement; \\
Learning Mind \\
Mapping \\
\hline
\end{tabular}


Kata Kunci:

Model

Pembelajaran;

Group

Investigation;

Learning Cycle

$5 E$; Prestasi

Belajar; Mind

Mapping

\begin{abstract}
Abstrak
Pendidikan di Indonesia secara teoretis menekankan pada kesuksesan yang diraih oleh peserta didik dalam suatu proses pembelajaran. Tujuan pendidikan di Indonesia adalah untuk menciptakan seseorang yang berkualitas dan berkarakter, Penelitian ini merupakan penelitian experiment dengan menerapkan dua model pembelajaran kooperatif yang berbeda pada siswa kelas V Sekolah Dasar Negeri 17 Dauh Puri pada tahun pelajaran 2016/2017 untuk mengetahui perbedaan prestasi belajar agama Hindu dan kreativitas siswa dalam bermain mind mapping. Data yang diperoleh akan dianalisis menggunakan dua metode analisa data yakni anava dan manova satu jalan. Anava satu jalan digunakan untuk mengukur perbedaan prestasi belajar agama Hindu dan kreativitas bermain mind mapping kedua model pembelajaran tersebut sedangkan manova satu jalan digunakan untuk menganalisis perbedaan prestasi belajar agama Hindu dan kreativitas bermain mind mapping siswa secara simultan. Hasil pengujian hipotesis diketahui bahwa metode pembelajaran yang diterapkan mempengaruhi prestasi belajar agama Hindu. Hal tersebut dibuktikan secara mutlak berdasarkan perolehan nilai rata-rata pada prestasi belajar agama Hindu siswa yang mengikuti model pembelajaran kooperatif tipe group investigation lebih rendah dari model pembelajaran learning cycle 5E. Secara simultan diketahui bahwa model pembelajaran kooperatif tipe group investigation dan larning cycle $5 E$ berpengaruh terhadap prestasi belajar agama hindu siswa namun kurang berpengaruh terhadap kreativitas siswa dalam bermain mind mapping. Berdasarkan hasil analisis efektivitas size diketahui bahwa model pembelajaran learning cycle $5 E$ dan model pembelajaran kooperatif tipe group investigation berpengaruh terhadap prestasi belajar agama Hindu siswa namun model pembelajaran learning cycle $5 E$ lebih mempengaruhi prestasi belajar agama Hindu siswa kelas V. Berdasarkan hasil uji efektifitas size maka diketahui model pembelajaran learning cycle $5 E$ lebih efektif diterapkan pada tingkat sekolah dasar.
\end{abstract}

\section{Pendahuluan}

Pendidikan di Indonesia secara teoretis menekankan pada kesuksesan yang diraih oleh peserta didik dalam suatu proses pembelajaran yang dilakukan dalam salah satu institusi atau lembaga pendidikan. Implementasi pendidikan yang dilakukan dengan cara berkesinambungan atau dapat diartikan memiliki tahapan- tahapan tertentu untuk memberikan hasil yang maksimal serta sesuai dengan tujuan yang diharapkan. Tujuan pendidikan di Indonesia adalah untuk menciptakan seseorang yang berkualitas dan berkarakter sehingga memiliki pandangan yang luas kedepan untuk mencapai suatu cita- 
cita yang di harapkan dan mampu beradaptasi secara cepat dan tepat di dalam berbagai lingkungan. Karena pendidikan merupakan motivator untuk berubah menjadi lebih baik dalam segala aspek kehidupan (Mulyasa, 2011:45).

Pendidikan yang dilaksanakan oleh institiusi pendidikan atau lembaga pendidikan berdasarkan perpektif empirisme memiliki empat tujuan yakni; (1) Mengaktualisasikan potensi peserta didik sehingga dapat digunakan dalam memecahkan berbagai masalah dalam kehidupannya; (2) Memberikan wawasan luas mengenai perkembangan karier peserta didik; (3) Memberikan bekal dengan latihan dasar tentang nilai yang berkaitan dengan kehidupan sehari-hari; (4) Memberikan kesempatan pada lembaga pendidikan untuk mengembangkan pembelajaran yang fleksibel yang sesuai dengan keadaan lingkungan setempat. Pendidikan atau pembelajaran juga dapat diartikan sebagai suatu cara memberikan ilmu dengan cara mendidik peserta didik melalui komunikasi dua arah atau transfer of knowledge (Abdurakhman, 2010: 9).

Berdasarkan perspektif empirisme yang diungkapkan oleh Abdurakhman, secara garis besar pelaksanaan pendidikan hendaknya memberikan manfaat sebagai berikut; (1) Mengaktualisasikan potensi peserta didik; (2) Memberikan wawasan atau pengetahuan; (3) Memberikan ketrampilan dan (4) Memberikan kesempatan pada instansi pendidikan untuk mengembangkan pembelajaran sesuai dengan kebutuhan. Namun, pelaksanaan proses pembelajaran saat ini apabila dilihat berdasarkan sudut pandang emperisme kurang maksimal. Hal ini dipengaruhi oleh beberapa faktor baik yang faktor intern maupun ekstern.

Pendidikan yang dilaksanakan oleh institiusi pendidikan atau lembaga pendidikan berdasarkan perpektif empirisme memiliki empat tujuan yakni; (1) Mengaktualisasikan potensi peserta didik sehingga dapat digunakan dalam memecahkan berbagai masalah dalam kehidupannya; (2) Memberikan wawasan luas mengenai perkembangan karier peserta didik; (3) Memberikan bekal dengan latihan dasar tentang nilai yang berkaitan dengan kehidupan sehari-hari; (4) Memberikan kesempatan pada lembaga pendidikan untuk mengembangkan pembelajaran yang fleksibel yang sesuai dengan keadaan lingkungan setempat. Pendidikan atau pembelajaran juga dapat diartikan sebagai suatu cara memberikan ilmu dengan cara mendidik peserta didik melalui komunikasi dua arah atau transfer of knowledge (Abdurakhman, 2010: 9).

Pelaksanaan pembelajaran dengan model teacher centered yang saat ini masih banyak diterapkan pada instansi-instansi pendidikan dapat menyita sebagian besar waktu 
belajar peserta didik untuk mendengarkan ceramah guru, menghafalkan materi dan mencatat materi. Ditinjau dari aspek relevansi mata pelajaran khusunya agama Hindu memerlukan adanya interaksi antara peserta didik dengan lingkungan sebagai sumber belajar, peserta didik dengan peserta didik dan peserta didik dengan Tuhan yang dalam ajaran agama Hindu dikenal dengan ajaran Tri Hita Karana.berdasarkan hal tersebut maka perlu dilakukan suatu inovasi dalam pelaksanaan pembelajaran agar dapat memaksimalkan potensi yang dimiliki oleh peserta didik.

Penerapan model pembelajaran yang inovatif dan kreatif akan memberikan kesempatan siswa untuk mengembangkan potensi-potensi dalam diri menjadi lebih maksimal. Inovasi yang dilakukan dalam hal ini adalah dengan menerapkan model pembelajaran kooperatif tipe group investigation $(G I)$ dan model pembelajaran learning cycle $5 E$.

\section{Metode}

Penelitian ini dapat dikatagorikan sebagai quasi eksperimental design. Quasi eksperimental design dalah eksperimen yang memiliki perlakuan (treatments), pengukuran-pengukuran dampak (outcome measures), dan unit-unit eksperiment (experimental units) namun tidak menggunakan penempatan secara acak. Pada penelitian lapangan biasanya menggunakan rancangan eksperiment semu (quasi eksperimen). Desain tidak mempunyai pembatasan yang ketat terhadap randomisasi, dan pada saat yang sama dapat mengontrol ancaman-ancaman validitas (Sugiyono, 2016: 168). Dalam proses pengumpulan data peneliti menggunakan metode observasi yakni pengamatan langsung dan tes yang terdiri dari soal-soal yang telah melalui proses validitas sebelumnya. Proses pengolahan data hasil penelitian menggunakan dua cara yakni menggunakan anova satu jalan dan manova satu jalan.

\section{Hasil dan Pembahasan}

Prestasi belajar agama Hindu yang dicapai oleh siswa yang mengikuti model pembelajaran kooperatif tipe group investigation dan learning cycle $5 E$ sangat signifikan. Hal ini didasari atas hasil analisis yang menyatakan bahwa nilai F hitung adalah 113,088 lebih besar dari nilai $\mathrm{F}$ tabel yakni 3,98 pada taraf signifikansi 0,05. Hasil perhitungan tersebut secara mutlak menyatakan bahwa terdapat perbedaan prestasi belajar agama 
Hindu siswa yang mengikuti model pembelajran kooperatif tipe group investigation dengan siswa yang mengikuti model pembelajaran learning cycle $5 E$.

Prestasi belajar agama Hindu siswa yang mengikuti model pembelajaran kooperatif tipe group investigation memperoleh nilai rata-rata 81,36 sedangkan nilai ratarata siswa yang mengikuti model pembelajaran learning cycle 5E 89,22. Data tersebut menyatakan bahwa prestasi belajar agama Hindu siswa yang mengikuti model pembelajaran learning cycle $5 E$ memperoleh nilai rata-rata lebih tinggi dari siswa yang mengikuti model pembelajaran kooperatif tipe group investigation. Selain itu, jumlah siswa yang mengikuti model pembelajaran learning cycle $5 E$ memperoleh nilai diatas rata-rata adalah 26 orang atau 72,22\% lebih tinggi dari jumlah siswa yang mengikuti model pembelajaran kooperatif tipe group investigation yang hanya berjumlah 7 orang atau $19,44 \%$.

Kreativitas bermain mind mapping siswa yang mengikuti model pembelajaran kooperatif tipe group investigation memperoleh nilai rata-rata 30,33 sedangkan nilai ratarata siswa yang mengikuti model pembelajaran learning cycle 5E 30,16. Data tersebut menyatakan bahwa kreativitas bermain mind mapping siswa yang mengikuti model pembelajaran learning cycle $5 E$ memperoleh nilai rata-rata lebih rendah dari siswa yang mengikuti model pembelajaran kooperatif tipe group investigation. Namun perbedaan nilai rata-rata kreativitas bermain mind mapping tersebut tidak memberikan pengaruh signifikan terhadap nilai kreativitas peserta didik baik yang mengikuti model pembelajaran kooperatif tipe group investigation maupun learning cycle $5 E$.

\section{Kesimpulan}

Berdasarkan hasil analisis dan pengujian hipotesis yang telah diuraikan maka dapat disimpulkan bahwa model pembelajaran kooperatif tipe group investigation dan learning cycle $5 E$ berpengaruh terhadap prestasi belajar agama Hindu dan kreativitas bermain mind mapping. Secara spesifik akan diuraikan sebagai berikut.

Pertama, secara keseluruhan dapat disimpulkan bahwa terdapat pengaruh prestasi belajar agama Hindu siswa yang mengikuti model pembelajaran kooperatif tipe group investigation dan siswa yang mengikuti pembelajaran dengan model learning cycle 5E. Prestasi belajar agama Hindu siswa yang mengikuti model pembelajaran learning cycle $5 E$ lebih baik dari siswa yang mengikuti model pembelajaran kooperatif tipe group investigation. 
Kedua, terdapat pengaruh kreativitas bermain mind mapping antara siswa yang mengikuti model pembelajaran kooperatif tipe group investigation dan model pembelajaran learning cycle 5E. Siswa yang mengikuti model pembelajaran kooperatif tipe group investigation memperoleh nilai rata-rata lebih tinggi dari siswa yang mengikuti model pembelajaran learning cycle 5E.

Ketiga, Secara simultan implementasi model pembelajaran kooperatif tipe group investigation dan learning cycle $5 E$ berpengaruh signifikan terhadap prestasi belajar siswa kelas $\mathrm{V}$ namun model pembelajaran tersebut secara simultan kurang mempengaruhi kreativitas siswa dalam bermain mind mapping.

\section{Daftar Pustaka}

Abdurrakhman. 2010. Esensi Praktis Belajar \& Pembelajaran. Bandung: Humaniora. Mulyasa, H.E. 2011. Manajemen Pendidikan Karakter. Jakarta: PT. Bumi Aksara

Putri, D. N. S. S. (2019). Implementasi Nilai Pendidikan Karakter Dalam Cerita Bhagawan Domya. Kamaya: Jurnal Ilmu Agama, 2(3), 184-194.

Sugiyono, 2016. Statistika Untuk Penelitian. Bandung: Alfabeta.

Suha, B. (2021). Social Media Activity dan Customer Experience dalam Membentuk Relationship Quality. Ganaya: Jurnal Ilmu Sosial Dan Humaniora, 4(2), 480490.

Windati, N. M. S., \& Sudarsana, I. K. (2020). Penanaman Sikap Inklusif Keberagamaan Hindu. Kamaya: Jurnal Ilmu Agama, 3(1), 94-101. 